\title{
CAMINHOS E (DES)CAMINHOS DA GESTÃO DEMOCRÁTICA DA ESCOLA PUBLICA: OBSTÁCULOS, RESISTÊNCIAS E PERSPECTIVAS PARA A DEMOCRATIZAÇÃO DOS CONSELHOS ESCOLARES
}

\author{
Celso Luiz Aparecido Conti ${ }^{1}$ \\ Maria Cecília Luiz ${ }^{2}$ \\ Sandra Aparecida Riscal ${ }^{3}$ \\ Universidade Federal de São Carlos - UFSCar
}

RESUMO

O presente artigo trata da gênese, forma, desenvolvimento e organização dos conselhos escolares. $\mathrm{O}$ estudo tem caráter histórico-político e o material de analise consistiu da produção historiográfica e bibliográfica produzida sobre o tema nos últimos vinte anos. Para a elaboração deste texto contamos com o aporte teórico dos seguintes autores, cujos trabalhos são dedicados ao estudos dos conselhos escolares, Abranches (2003);Andrade (2002); Aguiar (2008) Ciseski(2002); Benevides (2000); Bordignon e Gracindo (2000); Bruno (2002); Campos (1991) Cury (2000); Dourado (2004); Ferreira e Aguiar (2000); Krawczyk (1999);Luiz ( 2010a), ( 2010b ) ;Oliveira (2000) Paro, (2001), (2003); Riscal e Gandini (2002); Riscal ( 2009), (2010); Werle (2003). O estudo permitiu constatar que as lutas sociais, que levaram a introdução da gestão democrática na escola pública, criaram a expectativa de uma mudança nas relações de poder no cotidiano da escola, por meio da criação conselhos escolares participativos. A resistência de docentes e dirigentes escolares à dispositivos burocráticos e inócuos, incapazes de atender às reivindicações de democratização, levaram ao descrédito da população e em decorrência ao seu afastamento da gestão da escola.

Palavras-chave: Conselhos de escola; gestão democrática; democratização da escola publica.

\section{PATHS AND DETOURS OF DEMOCRATIC MANAGEMENT OF PUBLIC SCHOOL: OBSTACLES, RESISTANCE AND PROSPECTS FOR THE DEMOCRATISATION OF SCHOOL COUNCILS}

\begin{abstract}
The subject of this article is the form, the development and the organization of the school councils. The study has a historical and political character, and the materials used in this analysis are the historiographical and bibliographical literature on the subject in the last twenty years. For this paper we have the following theoretical contribution from authors who are devoted to the study of school councils: Abranches (2003), Andrade (2002), Aguiar (2008) Ali (2002); Benevides (2000), Bordignon and Gracindo (2000), Bruno (2002), fields (1991) Cury (2000); Gold (2004); Aguiar and Ferreira (2000); Krawczyk (1999); Luiz (2010a), (2010b), Oliveira (2000) Paro , (2001), (2003), Gandini and Riscal (2002); Riscal (2009), (2010); Werle (2003). The study concluded that the social struggles, which led to the introduction of the democratic management in the public school, created the expectation of a change in power relations within the school routine, by creating participatory school councils. The resistance of teachers and school directors to the full participation of the population in the political management of the schools, by introducing bureaucratic and innocuous devices thus unable to meet the democratization demands, led to the discrediting of the population and, in consequence, to its detachement from the school management.
\end{abstract}

Keywords: School councils, democratic management, democratization of public school 


\section{Introdução}

Uma revisão da literatura recente acerca dos estudos sobre a gestão democrática da educação no país, permitiu constatar que os Conselhos Escolares vem sendo considerados, nas últimas décadas, os principais instrumentos de democratização da escola e da educação pública no Brasil. Ademais, os diferentes estudos tem apontado, de uma forma geral, que os conselhos escolares podem ser um importante dispositivo para o aprendizado de práticas conselhistas e, por conseguinte de democratização da esfera pública. Intensos debates, iniciativas, programas governamentais e projetos acadêmicos tem tratado da implantação dos conselhos escolares trazendo à tona os conflitos decorrentes da sua ainda incipiente organização. Lutas pelo controle e pela determinação de sua forma de funcionamento, tanto pelas autoridades formais quanto pelas informais, vem caracterizando as experiências institucionais de conselhos, sugerindo a necessidade de uma maior reflexão sobre sua configuração, condições instalação e funcionamento. O processou de constituição políticohistórica dos conselhos escolares e seu desenvolvimento estrutural, vêm sendo atravessados por um conjunto de relações que determinaram sua condição de espaço de luta social. Compreender a gênese deste campo é compreender suas diferentes práticas, as distintas concepções que lhe estão associadas, os interesses que ali disputam o espaço de poder e as relações simbólicas que engendram.

Um dos primeiros aspectos a serem considerados para a compreensão das atuais práticas conselhistas nas escolas é a forma como a legislação incorporou os conselhos à estrutura escolar, ignorando as experiências que lhes deram origem. Durante as décadas de 1970 e 1980 movimentos sociais e populares se organizaram na forma de conselhos para reivindicar a universalização do acesso e democratização da escola. Essa demanda levou à introdução de dispositivos constitucionais e normatizações posteriores que induziram à criação de conselhos nos diferentes estágios da hierarquia burocrática das instituições educacionais. Esse processo, realizado por meio da burocracia estatal, separou os conselhos institucionalizados das lutas das quais eles resultaram, esvaziando seus propósitos e conteúdos emancipatórios. Apartado das práticas conselhistas populares, os conselhos foram reduzidos a meros aparatos gerenciais da escola. Esse esvaziamento de sentido e significado político dos conselhos, ocasionou o afastamento da comunidade da escola, que não reconheceu mais no conselho o seu aspecto emancipatório.

O propósito deste artigo é compreender em que medida, a forma adotada na implantação dos conselhos escolares, inverteram seu conteúdo, transformando-os em agentes gerenciais. Pretende-se compreender como os conselhos foram assimilados às estruturas burocráticas da escola, se afastando de sua proposta e proposito iniciais. Um dos grandes problemas que se pode constatar, que provocou o desinteresse pela participação da população nos conselhos escolares, foi exatamente o fato dele ter sido institucionalizado como colegiado da escola e identificado como parte da estrutura burocrática de gestão gerencial. Essa forma de institucionalização, ao invés de ser concebida como um prolongamento das manifestações populares das décadas de 1970 e 1980, efetivou-se como uma readaptação das antigas APMs (Associações de Pais e Mestres), testemunhando a resistência e permanência das relações de poder, criticadas pelos movimentos populares na organização escolar. A população que lutou pela democratização do ensino não se reconheceu como agente deste conselho, criado sob o impacto das concepções políticas neoliberais, de caráter gerencial.

Essa breve introdução permite concluir que, dependendo da perspectiva política adotada, podem ser caracterizadas diferentes formas de conselhos, assumindo feitios mais ou menos democratizantes. Compreender as diferentes formas e propostas assumidas pelo conselhos escolares é um importante passo para que se realize uma revisão do processo de 
implantação dos conselhos e para que se compreenda o abismo instaurado entre as práticas conselhistas gerenciais e as práticas democratizantes da comunidade, que um dia almejou ver-se nos conselhos representada. Para a realização deste artigo procurou-se, inicialmente, estabelecer uma tipologia funcional e política da forma conselhista, por meio do estudo de sua gênese histórico-política. Em seguida procurou-se estabelecer, dentre essas formas, aquelas que seriam próprias da participação democrática, partindo da análise das concepções de conselhos operários e autogestionários, inspiradoras das lutas por conselhos escolares. Finalmente, trataremos do processo da inclusão dos conselhos na legislação educacional brasileira, das propostas gerencial e conciliatória da organização política da escola.

\section{Distinção funcional e política das diferentes formas de conselhos}

Os conselhos são instituições sociais, que se constituem por meio de uma teia de relações nem sempre facilmente detectáveis, o que tem dificultado a identificação de um padrão de funcionamento típico. O processo de sua instauração deriva, fundamentalmente, dos diferentes interesses dos agentes políticos e escolares, não tendo sido, por isso, uniforme, homogêneo ou contínuo. A ausência de um processo de institucionalização ou da compreensão de qual seria o papel dos conselhos no espaço escolar acabaram por levar a implementação de estruturas baseadas em ensaios, sem a fixação de normas, com procedimentos que variam de acordo com os interesses do momento. A organização dos conselhos desenvolveu-se seguindo razões essencialmente localizadas e pragmáticas, principalmente por imposição da legislação, devendo muito pouco à vontade política dos agentes escolares. Por esse motivo, os conselhos assumiram aspectos predominantemente casuístas e personalistas, submetidos a direção da escola, reproduzindo as relações de poder predominantes. Em cada escola a direção, reconhecida como a autoridade máxima do conselho, e seu grupo de apoio, acabam por determinar a forma que este assume, sua composição, atribuições e regimento, privilegiando os temas que consideram mais pertinentes. A estrutura e função dos conselhos apresentam-se com diferentes formas e designações e as competências dos membros variam de casos em que são meramente consultivos a casos onde são legislativos e gestores da unidade escolar.

Não obstante a vasta literatura acadêmica sobre o tema, que inclui trabalhos de larga amplitude, de natureza quantitativa e qualitativa, com diferentes perspectivas de investigação e reflexão, o conhecimento acumulado sobre os conselhos escolares permanece ainda fragmentário. Tomados em conjunto verifica-se que, mesmo de forma segmentária, esses estudos constituem um valioso repertório de informações sobre as concepções e práticas dos conselhos. Essas informações permitem compreender que um dos principais obstáculos, para a implementação de conselhos democráticos, está na própria forma que estes devem assumir. A literatura existente tem tratado, em sua maioria, do papel dos conselhos na democratização da escola e são raros os estudos sobre a forma do conselho e sobre o papel desta forma, no regime de gestão da escola. No rol de problemas que vem sendo inventariados, questões de caráter formal como a forma de recrutamento dos membros do conselho, sua constituição, atribuições e funcionamento dos conselhos tem emergido como aspectos importantes para que ocorra um processo de democratização da escola.

Nosso intuito, nesta seção, é elaborar, por meio da discussão da forma institucional dos conselhos, um arcabouço analítico que permita estabelecer uma espécie de morfologia do conselho escolar, destacando seus aspectos interativos, dissociativos, democratizantes, privatizantes etc. 
Em geral, acredita-se que os aspectos formais não constituem o cerne do problema da democracia e por isso as discussões vem se concentrando nas ações dos conselhos e, em particular, em seu papel na democratização da escola. As ações do conselho não podem, entretanto, ser separadas da forma que o constitui. Questões como a forma como seus membros são recrutados (eleições diretas entre os pares ou indicação), a forma como se constitui o conselho (paritário ou se prevalece algum setor), as suas atribuições (consultivo, deliberativo), e até questões burocráticas, consideradas técnicas, como a forma de convocação para as reuniões, a existência de atas, formas de recursos a decisões, a periodicidade de reuniões, são aspectos importantes da formatação dos conselhos e determinam seu caráter mais ou menos democrático. Não se deve esquecer que a burocracia é uma forma de relação de poder, por isso é política e não simplesmente técnica. A forma não pode, portanto, ser separada do conteúdo do conselho, porque determina a pratica coletiva que constitui o seu modo de ser, os consensos e dissensões de sua ação como colegiado. Isoladamente, cada um desses elementos parece não ter significado senão técnico, mas tomados uns em relação aos outros, adquirem sentido político, como pratica coletiva.

O estudo da forma permite compreender em que medida as práticas, que constituem a ação coletiva, determinam as ações individuais e em que medida o indivíduo adquire existência e significado na interação social. (Re)formada e (in)formada pelos diferentes agentes, a forma constitui o modo de ser do grupo por meio da ação e inter-ação de seus diferentes membros. A forma, entretanto, não antecede, nem histórica nem temporalmente o indivíduo, como poderia pressupor uma concepção mecânica. A constituição da forma é um processo dialético que não pode ser diferenciado do processo que constitui a própria experiência concreta do indivíduo que dela participa.

A forma, anota Maffesoli (2007), decorre da própria experiência concreta de existir com e na experiência da interação do indivíduo com o todo. O termo concreto deriva do latim cum crescere, e denota um processo de crescer com, na ordem dinâmica que constitui afinal o vir a ser da forma. Informados, por suas maneiras de pensar, comportar-se, falar, os membros do grupo são assegurados de sua existência, assegurando-se uns aos outros por meio da forma totalizante. É o processo de formar-se e constituir-se por meio do grupo que faz do indivíduo parte dinâmica do todo, auferindo-lhe, assim, o sentido de pertencimento. Maffesoli (2007) denomina esse processo de "enraizamento dinâmico" que dá forma e sentido ao viver individual no coletivo. A forma é ordenamento e formatação dinâmica entre as diversas camadas de interação do indivíduo e da comunidade.

Por isso, deve atentar-se para o fato de que a forma como é organizado o conselho escolar constitui o fundamento de sua condição democrática, porque forma e (in)forma sua relação com a comunidade escolar. Mais do que criar um agrupamento, uma coleção de indivíduos justapostos, o conselho deve ser a fonte do processo de constituição de um espaço democrático, fundado na interação uma coletividade que se reconhece enquanto tal, organizada em torno de um projeto político. A proposta de constituição de conselhos visa não apenas o estabelecimento de um colegiado na gestão da escola, mas também, a introdução de novas formas de sociabilidade no coletivo escolar. Por esse motivo todos os seu aspectos informam (dão a forma) à vida comunitária da escola. Um conselho constituído de forma não democrática, com membros indicados por autoridades, reuniões esparsas, predominância dos docentes, informam à escola a permanência de relações de poder hierarquizado e centralizado e a impossibilidade de uma comunicação democrática. 


\section{As formas institucionais dos conselhos}

A forma como se processou a constituição político-histórica dos conselhos escolares, a sua gênese e desenvolvimento estrutural, são trespassados por um conjunto de relações que determinam sua condição de espaço de luta social. Compreender a gênese deste campo é compreender sua história, as concepções geradas, os interesses que ali disputam o poder e as relações simbólicas que engendram.

A constituição da atual forma institucional dos conselhos apresenta aspectos ambíguos. Se por um lado apresenta aspectos emancipatórios, decorrentes do processo de democratização da sociedade brasileira a partir da década de 1980, por outro lado, pode servir também de plataforma para a implementação de uma gestão gerencial na escola, como decorrência de sua reformatação neoliberal, nos moldes das organizações sociais, as OCIPS $^{4}$. Como observa Barroso, as reformas iniciadas na década 1980 exigiram alterações nos modos de regulação, nas formas de organização e nas práticas de gestão e introduziram novas formas de interação entre a esfera local e os demais poderes. (BARROSO, 1996) Esta nova formatação orientou-se no sentido de reforçar os aspectos de gestão fiscal e econômicos da esfera social, em detrimento das relações políticas.

A progressiva institucionalização dos conselhos tem decorrido, principalmente, da intervenção do Estado e em menor grau de iniciativas da comunidade, o que tem revelado muito mais o interesse governamental em delegar suas tarefas administrativas do que em desenvolver um processo de democratização do espaço escolar. A limitada autonomia da escola, cujas determinações curriculares, atribuições da equipe gestora e organização do trabalho emanam do Estado, permite a constatação de que não estamos diante de um processo de democratização que implemente uma real autonomia da escola. O único setor onde a autonomia escolar manifesta-se claramente é na gestão dos parcos recursos da escola.

Paradoxalmente, apesar das diferentes esferas da administração pública alardearem a necessidade de democratização e de gestão democrática da escola, nunca se observou um processo tão completo de burocratização de suas atividades, no que diz respeito à determinação curricular e ao elevado grau de controle e formalização, expressos pelos constantes regulamentos, relatórios e indicadores. São múltiplos os dispositivos de controle que visam, sem dúvida, reduzir o grau de liberdade local por meio de uma uniformização, homogeneização e padronização dos processos educativos. Professores, gestores e funcionários reclamam constantemente da quantidade de relatórios e planilhas a serem preenchidas. Além disso, a introdução de avaliações majoritárias, em larga escala, induzem a uma uniformização curricular e criam uma atmosfera impessoal no espaço escolar. Essa impessoalidade funciona como elemento que separa, em campos diferentes, as expectativas dos diferentes agentes da vida escolar: de um lado a equipe gestora e docente da escola, na busca de indicadores favoráveis; de outro lado alunos, que não encontram na escola espaço para a discussão das questões que lhes causam ansiedade; de outro, ainda, os pais e comunidade do entorno da escola, que esperam que a escola cumpra seu papel formador tanto do ponto de vista do conhecimento quanto do ponto de vista ético e social. É preciso, portanto, que se pergunte -quais formas e constituição os conselho de escola deveriam adotar para que todos os setores encontrem seus interesses representados?

Paradoxalmente, o conhecimento sobre o processo histórico de constituição dos conselhos ainda permanece disperso e fragmentado, apesar dos recentes esforços investigativos e analíticos. Investigar as formas de que podem assumir os conselhos significa compreender as modalidades relacionais, os jogos de poder entre os diversos sujeitos e os níveis hierárquicos que estão envolvidos em sua criação e funcionamento. 
Não se pode tomar o conceito de conselhos escolares como uma forma geral e abstrata, mas deve-se, antes, partir das formas de experiências históricas vinculadas aos processos sociais, políticos e culturais concretos que as geraram.

Um estudo preliminar do problema permitiu que elaborássemos algumas distinções iniciais sobre os diferentes aspectos que podem apresentar os conselhos. Do ponto de vista funcional, podemos encontrar conselhos consultivos, deliberativos e gestores. Os conselhos consultivos estão entre as mais antigas formas de conselhos e têm como finalidade apresentar opiniões, proposições e alternativas para outra instância hierarquicamente superior. Os conselhos deliberativos podem ter caráter legislativo, elaborar as leis, ou exercer a justiça. Constituem, neste caso o poder supremo e deliberam em última instancia. Os conselhos gestores, por sua vez, têm caráter executivo, atuam apenas na implementação das políticas elaboradas por outra instancia superior. Quanto à dimensão política de sua atuação, podemos encontrar conselhos deliberativos de caráter emancipatório ou de legitimação. Chamaremos de conselhos de caráter emancipatório àqueles conselhos cuja atuação busque a superação das condições de subordinação, reprodução e conformação. Nesta forma, os conselhos se dedicam não apenas à deliberação sobre problemas a eles encaminhados mas debatem as condições da instituição que representam, levantam problemas e apresentam planos de ação para sua superação. Os conselhos com caráter de legitimação são, em geral, de natureza conciliatória, se atém às tarefas a eles encaminhadas por setores hegemônicos, acompanham ou referendam as posições vigentes e reproduzem as formas de controle e subordinação impostos à instituição que representam. Falta a esta última forma de conselho, a autonomia, que constitui a própria essência do caráter emancipatório.

Para compreender a natureza da atuação dos conselhos, apresentamos, a seguir, algumas anotações sobre a gênese da forma "conselho", como instancia de deliberação política, enfatizando seu aspecto consultivo, deliberativo ou gestor.

\section{Conselhos: gênese das diferentes formas e contexto histórico}

De uma forma geral, a implantação da forma de deliberação política baseada em conselhos teve origem na necessidade, percebida por diferentes sociedades, de estabelecer formas de iteração e cooperação entre agentes políticos em conflito. Cury observa que a ideia de conselho remete à noção de deliberação refletida e ponderada, a partir de uma recíproca audição, o que dá ao conselho um caráter de interação publica:

Conselho vem do latim Consilium. Por sua vez, consilium provém do verbo consulo/consulere, significando tanto ouvir alguém quanto submeter algo a uma deliberação de alguém, após uma ponderação refletida, prudente e de bom-senso. Trata-se, pois, de um verbo cujos significados postulam a via de mão dupla: ouvir e ser ouvido. Obviamente a recíproca audição se compõe com o ver e ser visto e, assim sendo, ou de partes destes, o próprio verbo consulere já contém um princípio de publicidade (CURY, 2000, p. 47).

O conselho é, no sentido indicado por Cury, mais do uma instituição, um processo de avaliação razoável, isto é uma mediação racional onde todos consideram e pesam racionalmente, os argumentos uns dos outros com vistas a uma decisão compartilhada. $\mathrm{O}$ principal aspecto da decisão dos conselhos é o seu caráter coletivo, porque não expressam a opinião de um indivíduo, mas a posição de um corpo político.

A trajetória dos conselhos, como estruturas políticas coletivas, pode ser acompanhada desde a antiguidade. Os conselhos antigos podiam ter a forma de conselhos 
de anciãos cuja principal função era a manutenção da ordem tradicional e a conservação das relações políticas e sociais. Nestes casos, as concepções políticas e religiosas não se distinguiam e os conselhos podiam assumir tanto o papel de aconselhamento político como de manutenção da ordem e da religião. Na literatura histórica encontram-se registros de diferentes instituições políticas, na forma de conselhos, nas organizações sociais mais arcaicas, como no caso dos clãs, tribos ou fatrias. São frequentes referências a conselhos com os mais diferentes caracteres, seja consultivos, de assessoramento ou deliberativos, na forma de conselho de anciãos, de sacerdotes, guerreiros ou notáveis. $\mathrm{Na}$ antiga Mesopotâmia podiam-se encontrar registros de conselhos com o papel de aconselhar monarcas em aspectos religiosos. Na Ilíada e Odisseia são comuns as referências aos conselhos de reis. Descrições de conselhos oligárquicos ou conselhos sacerdotais mesopotâmicos e egípcios podem ser encontradas na História de Heródoto, mas é na Guerra do Peloponeso, de Tucidides, que pode ser encontrada a mais famosa descrição de um conselho na antiguidade e que permanece como arquétipo desta forma uma organização política até os dias de hoje: a Gerúsia. Criada por volta do século VIII A.C a Gerúsia tinha poder legislativo e era constituída pelos anciãos da antiga Esparta. Outras referências a conselhos de anciãos podem ser encontradas relatos bíblicos das tribos de Israel datados da primeira metade do século I A.C. (I Reis 12,8, I Reis 12,13II Crônicas 10,14, Salmos 106 ,32, II Macabeus 11,27).

A expressão conselho admitiu ao longo da antiguidade duas concepções bem distintas entre si, aquela que enfatizava o seu papel de aconselhamento, determinando seu papel como consultivo e outra que compreendia o conselho com poder legislativo. A concepção do conselho como organização política legislativa, responsável pelo ordenamento legal da esfera pública, aparece de forma explicita nas primitivas organizações políticas etruscas, por volta de 600 A.C., que mais tarde deram origem ao senado romano. Conselhos com papel deliberativo e legislativo permaneceram, sob diferentes formas, durante toda a evolução política romana, chegando ao período medieval. No direito canônico encontramos a figura do Consilium Episcopale, conselho para deliberação dos assuntos públicos da Igreja. Também em vários dos reinos bárbaros encontram-se conselhos de notáveis ou da elite guerreira assessorando os reis.

Em meados do período medieval, uma nova configuração de organização política na forma de conselhos entra em cena: os conselhos de caráter emancipatório, orientados para a luta por liberdade política. A partir do século VIII, as organizações de artesãos e comerciantes começam a assumir a forma de conselhos, dando origem às comunas medievais. A comuna foi o gérmen dos conselhos municipais e constituiu importante instrumento para a emancipação das cidades comerciais, frente aos poderes feudais. $\mathrm{O}$ termo comuna passou gradualmente a designar as cidades que recebiam as cartas de autonomia (carta comunal ou no caso português cartas forais) dos senhores, reis, papa ou imperador. Ainda hoje o termo é usado para designar subdivisões territoriais em diversos estados europeus. A concepção das comunas, como conselhos de caráter emancipatório, permaneceu no imaginário político até o século XX e forneceu as bases para a concepção de conselhos de trabalhadores contemporâneos.

Já a concepção de conselho como órgão de aconselhamento permaneceu na figura de conselheiros reais. Conselhos assessores dos reis foram comuns entre as monarquias partir do século XIII e a maioria dos reis europeus dos séculos XVI ao XVIII mantiveram um Conselho Privado, com funções de elaboração de estratégias políticas, militares e aconselhamento em matéria econômica.

A concepção do conselho como instrumento de emancipação assumiu seu caráter mais extremado na França do século XVIII. Durante o processo revolucionário francês 
foram implantados diversos conselhos que assumiram a forma de comitês e foram responsáveis pela administração e ações políticas. A partir da experiência revolucionária francesa os conselhos foram associados às manifestações de luta pela autonomia política, como no caso dos Comitês populares autogestionários da Comuna de Paris em 1871.

\section{Aspectos teóricos da concepção de conselhos emancipatórios: os conselhos de operários}

A concepção de conselhos como instrumentos de emancipação política aparece a partir do século XIX sob a forma autogestitonária ou de conselhos operários, com o proposito revolucionário de substituir a forma de poder estatal. Rotolo observa que as formas iniciais dos conselhos contemporâneos foram importantes em momentos revolucionários, como no caso da revolução francesa, da Comuna de Paris e dos sovietes etc. O sentido da ação dos conselhos, na forma de emancipação política, visa o exercício mais democrático do poder, ampliando as formas de participação popular. É, portanto, um modo de gerir as decisões políticas com base na participação efetiva de todos, seja na administração das fábricas, de bairros ou, em nível maior, na gestão do Estado. (ROTOLO, 2007, 87)

As iniciativas de conselhos operários constituidas durante a Comuna de Paris de 1871 inspiraram os soviets (termo russo para conselhos) instaurados na Russia, em 1905. A partir da Revolução Russa de 1917, os conselhos operários emergiram como uma das principais estruturas de participação política operária. Conselhos também emergiram na Hungria e Itália entre 1919-1920. Durante a revolta espartaquista, ocorrida na Alemanha entre 1918 e 1919, surgiu uma corrente que, a partir da experiência sovietica, desenvolveu uma teoria sobre o papel revolucionário dos conselhos operários. Os conselhos populares tiveram importante papel no breve período de republica e guerra civil espanholas de 1936 1939. Mais tarde voltam a aparecer na revolução dos Cravos, em Portugal, em 1974 e na Polônia, na década de 1980, com o movimento Solidarienosc. Na Alemanha de 1918, durante o período de lutas dos trabalhadores chegaram a existir cerca de 10 mil conselhos, na Hungria foi instaurada, neste mesmo período uma "República Húngara dos Conselhos", e na Itália, entre 1919 e 1920, contava-se com cerca de 150 mil conselhos. Estes processos tiveram um curto período de duração e logo foram abortados. Entretanto, compreender o caráter e concepção destas experiências de conselhos pode ser de grande valia para a determinação de uma forma mais democrática de organização dos conselhos.

Foi com os soviets russos que a concepção de conselhos assumiu o caráter revolucionário, se tornando o centro dos debates sobre a organização da classe trabalhadora e dos movimentos populares. A organização operária que deu inicio ao Estado Soviético foi baseada na estrutura dos soviets. Surgidos em 1905, durante a insurreição armada, os sovietes eram inicialmente conselhos populares e, em 1917, passaram a constituir oficialmente a estrutura politica. Dominada por deputados socialdemocratas e mencheviques, a politica implementada levou Lenin a proclamar as teses de Abril, onde proferiu a famosa frase - Todo poder aos soviets. Lenin conclamou os bolcheviques a tranformar os sovietes em estruturas verdadeiramente revolucionarias, ao invés do caráter pequeno burguês que vinham assumindo desde fevereiro de 1917. Para Lenin o caminho da revolução era a ditadura do partido bolchevique organizado como soviete ou Estado comuna. (GETZLER, 1985) A partir da revolução de 1917, a estrutura piramidal de soviets, formado por comissarios eleitos diretamente pela população, tornou-se a base do Estado Sovietico. Na base estavam os soviets das fábricas, dos trabalahadores da cidade e do campo. Nos niveis superiores encontravam -se soviets de distritos e de províncias, 
formado por comissários eleitos pelos represetantes dos soviets inferioes. Acima de todos estava o supremo soviet, que designava os membros do Conselho dos Comissários do Povo (CCP), o governo do país. Tragtemberg (2004) observou que a estrutura de soviets, baseadas no sistema de comitês de representantes, implementada pelo Partido Bolchevique, acabou por promover, na verdade, uma contra-revolução burocrática, porque o partido assumiu o poder estatal e passou a controlar, de forma centralizada, toda a sociedade.

No período que se sucedeu à revolução russa de 1917 e à Primeira Guerra Mundial, a temática dos conselhos foi abordada por diversos pensadores do campo marxista. Foi na Alemanha no período entre 1918 e 1921 que ocorreram os mais intensos debates sobre a concepção que veio a ser denominada de conselhista. A repressão à atuação dos sindicatos e o descontentamento com as concepções leninistas, levou organizações operárias alemãs a buscarem outra forma de expressão, que substituísse a organização por profissões, características dos sindicatos da época. A nova organização, de conselhos por empresa, mostrou-se rapidamente mais eficiente e abrangente, porque possibilitou que o movimento não se reduzisse a minoria de trabalhadores sindicalizados que constituíam a vanguarda sindical. Por meio dos conselhos (Räte) foi organizado o movimento grevista de $1917 \mathrm{e} \mathrm{em}$ 1918, formando o primeiro Conselho Operário da Grande-Berlim, composto por delegados de conselhos de diversas empresas e constituído segundo o modelo do soviete de Petrogrado. (AUTHER, 1975)

Uma das mais importantes estudiosas da forma de gestão por meio de conselhos foi Rosa Luxemburgo ${ }^{5}$, uma das líderes do partido espartaquista na Alemanha. Em oposição à concepção leninista baseada no partido e nos comitês de representantes, Luxemburgo defendia a concepção de que os conselhos deveriam constituir uma nova maneira de articular o indivíduo e a coletividade. Segundo sua ótica, os conselhos seriam espaços de realização da liberdade humana e de afirmação das individualidades, porque neles se poderia estabelecer, por meio da palavra, a interação entre desejos individuais e interesses coletivos, em função do bem comum. Para Rosa Luxemburgo, o socialismo seria impossível sem liberdade de pensamento e de discussão e os conselhos encarnariam o seu verdadeiro ideal: neles os homens podem decidir sobre os assuntos públicos de maneira igual, tendo igualmente o mesmo acesso às decisões e o mesmo peso político (ROTOLO, 2007, 95). Neste sentido, os conselhos representavam o elemento vivo do poder exercido pelas massas e deveriam exercer as tarefas do Executivo e do Legislativo, constituindo uma nova estrutura de poder, mais participativa e mais democrática.

A senda aberta por Luxemburgo e pelos espartaquistas foi trilhada também pelo astrônomo holandês Anton Pannekoek. Retomando os principios marxistas, Pannekoek defendeu a idéia de que a emancipação dos trabalhadores deve ser obra dos próprios trabalhadores e que os conselhos seriam um dos principais agentes do processo revolucionário, que deveria ser fundado em um sistema de autogestão. Tanto espartaquistas quanto Pannekoek enfatizaram um aspecto fundamental da concepção conselhista, o processo de participação coletiva e de autogestão, como forma de promoção da autonomia e liberdade humanas. Os conselhos não consistiam apenas em orgãos de administração, mas estruturas de democratização do poder, que estabeleceriam uma nova forma de interação democraticas entre os homens.

Em uma outra direção foi o caminho estabelecido por Antônio Gramsci, pensador marxista que exerceu grande influência no movimento de formação de conselhos operários italianos. Entre os anos de 1919-1920, seus escritos em L'Ordine Nuovo influenciaram diretamente a formação de conselhos de trabalhadores na Itália. Para Gramsci a democracia operária só seria possível com a organização do trabalhador na fábrica, por meio de conselhos que deveriam, futuramente constituir um Estado dos Conselhos 
(GRAMSCI, 2004, 272). Nessa nova constituição estatal, o sistema de conselhos seria a base de uma rede de instituições, na qual, o processo revolucionário se desenvolveria. $\mathrm{O}$ conselho constituiria a formação histórica da sociedade, nascida da autoconsciência do trabalhador, para dominar o aparelho de produção e seria um dos instrumentos de propulsão do processo revolucionário, (GRAMSCI, 2004 312).

Pode-se concluir, de uma forma geral, que as diferentes experiências conselhistas operárias, populares ou autogestionárias, foram importantes formas de organização emancipatórias no século XX. Esses eventos influenciaram movimentos sociais por todo o mundo e inspiraram as manifestações populares ocorridas no Brasil, durante o período militar e as lutas contra a carestia e pela universalização e qualidade do ensino, nas décadas de 1970 e 1980.

\section{As experiências conselhistas no Brasil e a luta pela democratização da escola publica}

Os debates em torno da forma dos conselhos operários, no período de 1917 a 1920 , constituíram as bases sobre a qual se estabeleceram as atuais concepções conselhistas. Seu caráter emancipatório era a base tanto das proposições autogestionárias como das propostas de comitês de gestão operários. Essas concepções podem ser encontradas nas ideias propagadas entre os movimentos sociais, em prol de gestão democrática, nas décadas de 1870 e 1980 no Brasil. De uma forma geral, segundo Gohn (2001), os primeiros conselhos na história do Brasil foram criados pelo próprio poder executivo, para mediar suas relações com a sociedade. A partir do período de democratização e com a introdução da gestão democrática na Constituição de 1988, a concepção de conselhos foi introduzida na gestão dos setores governamentais voltados para o atendimento social. Em particular, as áreas de educação, saúde e assistência social passaram a ser administradas por comitês gestores. Embora as propostas de conselhos tenham surgido dos movimentos e organizações populares, a fim de estabelecer um espaço negociações, muitos conselhos foram institucionalizados e assumiram o papel de gestores dos negócios públicos.

\section{Os conselhos e os movimentos populares em São Paulo}

Nos anos 1970 a demanda popular por educação levou a manifestações em prol do uso coletivo de equipamentos públicos na periferia de São Paulo. O modelo de crescimento econômico, implementado durante o período militar, resultou em uma concentração de riqueza que excluiu as camadas populares do usufruto desenvolvimento, intensificando as desigualdades sociais. O surgimento de movimentos contra a carestia, com milhares de pessoas tomando as ruas em protesto contra o elevado custo de vida, levou os governos federal e estaduais a estabelecerem formas de participação popular consentidas, de caráter clientelista, por meio das Sociedades Amigos de Bairro - SABs e Associações de Pais e Mestres, as APMs. No final da década de 1980, até o início do período de redemocratização ampliaram-se, na periferia de São Paulo, movimentos de mães por creches, por cursos de segundo grau e supletivos. (SPOSITO, 1984)

Durante o período das manifestações populares foram criadas, em São Paulo, formas rudimentares de estruturas conselhistas. Em 1977 o Regimento Comum das Escolas estaduais (Decreto $\mathrm{n}^{\circ} 10.623 / 77$ ) criou os Conselhos de Escola com caráter consultivo. O Estatuto do Magistério, $\mathrm{n}^{\circ} 42 / 78$, no artigo $3^{\circ}$, inciso IV, determinou que o Conselho de Escola teria suas atribuições definidas por Regulamentos (do poder executivo). Encaminhado para sanção, o inciso foi vetado pelo então governador Paulo Egydio Martins. 
Segundo Abranches (2003), no início da década de 1980 surgiram projetos em diversos estados e municípios brasileiros, voltados para a gestão democrática da escola. Propostas de eleição direta para diretor de escola, organização de conselhos escolares e administração colegiada, visavam a implementação de uma administração coletiva. A participação de todos nos processos decisórios, no acompanhamento, execução e avaliação das ações nas unidades escolares; nas questões administrativas, financeiras e pedagógicas, parecia um horizonte possível e realizável com o processo de democratização.

Em resposta aos movimentos sociais, governantes do estado de São Paulo apresentaram propostas e reformas da organização escolar com o propósito de atender às reivindicações de democratização da escola. Em 1984, durante o governo de Franco Montoro em São Paulo, foram criados os Conselhos de Escola deliberativos por meio da Lei complementar $n^{\circ} 375 / 84$, que transformou o caráter do conselho de consultivo em deliberativo. O Estatuto do Magistério de $n^{\circ} 444 / 85$, em seu artigo 95, determinou, dentre as atribuições do Conselho de Escola, deliberar sobre as diretrizes e metas da unidade escolar. Não foi prevista, entretanto, a participação da comunidade, apenas de docentes 40\%; especialistas; 5\%, funcionários; 3\% e alunos 25\%. (SÃO PAULO, 1985)

Segundo Aredes (2002) durante o governo no estado de São Paulo de Antonio Freury Filho (1991 - 1995) quando foi implementado o projeto Escola Padrão, a influência das doutrinas neoliberais determinaram uma nova concepção do conselho escolar. A essência da proposta era a preocupação com o gerenciamento tecnicamente eficaz e eficiente da unidade escolar. Isso exigia, entretanto, o fortalecimento do conselho e a participação da comunidade. Apesar de seu caráter gerencial, o projeto abriu espaço para a participação dos pais na gestão da escola, por meio da APM.

Durante o governo de Mario Covas (1995-2002) em São Paulo, a participação da comunidade assumiu papel importante na adoção de práticas gerenciais, priorizando as atividades de definição das necessidades materiais da escola e de planejamento dos gastos dos recursos a ela destinados. A escola assume o papel fiscal de unidade executora, gerida por um conselho executivo, cujo fundamento encontra-se na concepção de que a comunidade escolar deveria decidir sobre a gestão dos recursos financeiros.

\section{Os conselhos escolares e a gestão democrática da educação após a Constituição de 1988}

Os projetos dos governos paulistas da década de 1980, que estabeleceram conselhos escolares de natureza deliberativa, influenciaram os movimentos sociais em favor da gestão democrática da escola durante o período constituinte em 1988. A partir da Constituição de 1988, motivadas pelos movimentos sociais, são apresentadas propostas governamentais com vistas a promover a participação da população na gestão política das escolas.

As propostas de conselhos, defendidas pelos movimentos sociais, constituiam, em sua origem, uma forma de organização popular com o objetivo de reivindicar uma nova forma de organização das estruturas de poder que democratizassem o espaço publico. Eram, essencialmente, uma forma de organização fora da esfera estatal, e exigiam a adoção de politicas publicas, pelo Estado, em áreas como educação, saúde, infancia. Essas lutas permitiram a incorporação na Constituição de 1988 desses direitos sociais que incluiu a gestão destas politicas publicas por conselhos gestores.

A institucionalização da proposta de conselhos escolares, não obstante, constituiu um processo apartado dos movimentos sociais. Estabelecidos como dispositivos burocráticos e impessoais, na forma da lei, os conselhos perderam o conteúdo inovador e 
emancipatorio, tornando-os subordinados a tradicional estrutura estagnada e rigida das escolas. Foram deixados fora dos muros escolares a impulsão democratica cinestésica que dava ao movimento seu carater inovador.

Um dos principais aspectos que determinou o retrocesso do processo de democratização foi a adoção de politicas de caráter neoliberal na década de 1990. A Constituição de 1988 foi elaborada em meio a uma esfervecente atmosfera de lutas e movimentos sociais, que tinham fervilhado durante o final do período militar, e, por isso, incorporou inumeras reivindicações de democratização e de gestão democratica da esfera pública. Na década de 1990, as mudanças conservadoras na esfera política nacional, que culminaram com a eleição para a presidência da república de Fernado Collor de Mello (1990-1992), levaram a um retorcesso na adoção de politicas públicas democraticas. Os agentes politicos conservadores passaram a defender proposições tipicamente neoliberais, que implicavam, inversamente ao que se propusera durante o processo constitucional, na retirada da responsabilidade do Estado na implementação de politicas sociais, que agora seria entregue ao setor privado. Essa concepção foi adotada e defendida com ainda maior veemência durante os dois mandatos do presidente Fernando Henrique Cardoso (19952003). Seu ministro da educação, Paulo Renato Costa Souza, implementou uma reformulação das estruturas educacionais, adotando uma perspectiva de eficiencia e eficiácia fundamentadas na gestão empresarial. Decorreu daí uma desarticulação e reestruturação da gestão publica, por meio de um processo que ficou conhecido como Reforma do Estado. Essa reestruturação adaptou a concepção de conselhos escolares à percepção gerencial, retirando seu carater político, tornando-os meros administradores de receita. Destituídos de seu conteúdo politico, os conselhos perderam seu caráter popular e consequentemente a pulsão que lhes imprimia um caráter transformador.

Esvasiados do processo politico que levou à sua constituição, os conselhos perderam o sentido e significado politico para os setores populares. A origem dos conselhos escolares e da gestão democratica passou a ser oficialmente datada pelo momento em que foram incorporados pela legislação, como norma legal, sem que se reconhecesse sua fonte no ideário dos movimentos populares. Essa nova notação desvinculou os conselhos da territorialidade que os engendrou e do movimento que os produziu. A desterritorialização dos conselhos, da escola e, em decorrência, do espaço comunitário levaram ao afastamento dos setores populares. Se no momento de ebulição popular, observa Maria Malta Campos (1991), a escola era concebida como um ponto importante de referencia nos bairros e na vida comunitaria, com a nova legislação ela assume a forma de um corpo estranho e alienado em relação à vida local. A escola, que antes era o lugar do exercicio civico, do voto, da vacinação comunitaria, do refugio seguro às inundações e o lugar de festas em feriados é, agora, espaço descaracterizado de um poder não reconhecido (Campos,1991). A escola reconstituída na década de 1990, tornouse espaço gerenciado, organizado segundo uma lógica de eficiencia e metas estabelecidas por agentes exteriores a esfera local e portanto, sem significado. A escola torna-se um espaço deslocado, não reconhecida como local de trabalho pelos docentes e gestores (que em geral não moram no bairro da escola e pretendem a remoção para uma escola mais proxima de sua casa) e não reconhecida pela comunidade porque nada nela a enraiza no local onde se situa. A escola tornou-se, portanto, um espaço de alienação dos agentes escolares, resultante da perda do sentido e do significado do trabalho escolar, desumanizado e despersonalizado.

Sposito (1989) observa que mesmo nos momentos de maior abertura política das escolas, vários mecanismos foram acionados com o intuito de dificultar a maior inserção popular. Não houve uma mudança significativa no caráter clientelista das APMs, o que 
sinaliza a permanência de práticas políticas tradicionais, de sujeição, nas relações entre representantes dos poderes públicos e representantes da população. Ao invés de se reconhecer as formas de participação promovidas pelos movimentos sociais, foram apresentadas propostas de participação induzida pelos governos, com diferentes estruturas e finalidades, motivo pelo qual, na maioria das vezes, não encontraram apoio na comunidade usuária da escola pública, que rejeitou e se negou a uma participação tutelada.

Segundo Sposito a população teria se sentido, de certa forma, ludibriada porque paradoxalmente, ao conquistar o direito à educação e o acesso à escola, os agentes dos movimentos teriam percebido que a escola pela qual lutaram não era exatamente a que teriam recebido, o que os teria levado a questionar os sentidos da luta e da educação. (SPOSITO, 1988)

\title{
As formas dos Conselhos escolares após 1988
}

A seguir procuraremos estabelecer em que medida as formas de conselhos tais como são implementados nas escolas, podem ser, de fato, concebidas como democráticas e emancipatórias.

Segundo Abranches (2003) a descentralização da escola só se torna possível quando há uma mudança real no processo de decisão, por meio do deslocamento dos centros decisórios. A abertura do espaço físico da escola para a participação da comunidade proporciona uma transformação na percepção que se tem da escola, que passa de propriedade do Estado para espaço público. Essa apropriação do espaço escolar pela comunidade gera uma transformação na sua representação da vida escolar e estimula esforços no sentido da cooperação e de um aprendizado de convivência.

\begin{abstract}
A proposta é entender a democratização como a real participação da sociedade civil nas discussões públicas, possibilitando a concretização de uma dinâmica que permita o aprendizado e o amadurecimento político da comunidade a partir da efetivação de estruturas participativas. (ABRANCHES, 2003, p.12)
\end{abstract}

A constituição de uma nova dinâmica social é, por certo, um processo demorado que implica em um estágio de formação e aprendizagem do que é a vida democrática e exige a incorporação de novas formas de interação social e política. A institucionalização da participação, por si mesma, não efetiva a participação democrática que exige uma certa paciência politica.

A institucionalização de espaços de decisão e participação nas políticas públicas e no interior da escola é, por certo, uma vida de formação e aprendizagem individual e institucional. (ABRANCHES, 2003, p. 41)

A política educacional brasileira, implementada nas três últimas décadas, estabeleceu a organização colegiada nas diferentes instâncias e níveis da educação nacional. Do Conselho Nacional de Educação aos Conselhos Estaduais e Municipais, é função destes conselhos definir, em sua esfera de atuação, as políticas educacionais a serem implementadas. (Riscal, 2010)

A partir da década de 1990 o debate sobre os conselhos escolares ganhou fôlego e uma série de estudos sobre conselhos escolares foram publicados. Em particular os trabalhos de Abranches (2003), Andrade (2002), Ciseski(2002), Aguiar (2008) Bordignon e Gracindo (2000)Bruno (2002), Cury (2000), Dourado (2004), Gohn (2001), Krawczyk, (1999), Luiz (2010), Oliveira (2002), Paro ( 2001;2006), Riscal (2009; 2010), Luiz (2010;2013); Sposito (1993) Werle (2003) tem enfatizado o papel fundamental dos 
Conselhos Escolares na constituição de uma escola pública democrática. Trata-se de um espaço fundamental de descentralização da gestão escolar e socialização do poder.

A natureza das atividades dos conselhos não é clara e nem unanime. Na forma como é apresentado na legislação, o conceito de conselhos escolares apresenta um caráter ambíguo e pode assumir diversas formas e funções, que podem ser de natureza deliberativa, consultiva, avaliativa, financeira ou fiscalizadora, dentre outras. De uma forma geral, espera-se que os conselhos escolares exerçam atividades deliberativas em relação aos destinos da vida escolar. Entretanto a forma como foram inicialmente institucionalizados imprimiu aos conselhos uma feição de colegiado auxiliar da gestão da escola, voltado para atividades de gestão financeira e fiscalização econômica. Nem sempre é claro ou explicito o papel do conselho na elaboração do Projeto Político Pedagógico da escola ou do Regimento Escolar. Em muitos casos persiste o papel identificado às Associações de pais e mestres, voltados para a gestão dos recursos da escola.

Como anotou Spósito (1993) as formas tradicionais de participação dos pais e da comunidade na escola não permitem o reconhecimento do espaço escolar como dimensão pública e socializadora e portanto não introduzem valores democráticos na vida escolar e social. Mesmo nos casos em que o conselho apresenta caráter deliberativo, com o papel de direcionar as políticas desenvolvidas no âmbito da escola, é comum encontrar-se obstáculos interpostos pelos próprios grupos sociais que a constituem. Em particular, as decisões relativas às diretrizes pedagógicas são deixadas fora das atividades dos conselhos.

De uma forma geral, boa parte dos conselhos assumem caráter consultivo, restringindo suas atividades à emissão de pareceres ou dirimindo dúvidas. As ações que tratam de identificação de problemas, as busca de soluções, o planejamento e avaliação das atividades pedagógicas acabam sendo atribuídas à equipe pedagógica da escola que não reconhece nos membros do conselho a competência para atuação nesta área. No máximo deixam ao conselho a atuação de fiscalização do cumprimento das normas, principalmente nos casos em que são necessárias a aplicação de sanções a algum membro da comunidade escolar. Neste caso, o conselho assume um caráter de legitimação das relações de poder e hierarquia da escola. Para Barroso (1996) a criação nas escolas, de um 'grupo político', constituído por professores, pais e estudantes, com a função de determinar as metas, definir e avaliar políticas e prioridades, constitui parte do processo de gerenciamento, que visa melhorar simultaneamente a sua eficiência externa, a serviço da economia do país e a sua eficiência interna, de modo a justificarem o dinheiro que se investe nelas. A escola passa a ser gerida como uma empresa, no quadro de um sistema de concorrência em que a satisfação do consumidor decide da sua rentabilidade e eficácia.

Os pressupostos de base neoliberais que nortearam a política de descentralização da gestão escolar e a implantação de conselhos escolares também correspondem a um processo de desresponsabilização do Estado em relação às políticas sociais e transferência de tarefas de gestão financeira, que antes estariam no escopo do Estado.

Em vez de dotar de poder político os agentes sociais capazes de efetivar uma política administrativa pública, que correspondessem às aspirações as sociedade, o que ocorreu foi uma reordenação e regulamentação dos objetivos sociais por parte dos agentes administrativos do Estado. (RISCAL;GANDINI, 2002,46)

Isso significa que a existência de conselhos, ainda que deliberativos, não garantem, automaticamente, a democratização da instituição. Dependendo da forma e função do conselho e das condições de arregimentação de seus membros, os conselhos podem ser mais ou menos democráticos. Os conselhos podem existir em Estados autoritários ou ditatoriais como foi o caso da junta militar responsável pelo golpe militar em 1964. A 
forma colegiada de organização pode assumir as mais diferentes formas de poder e podem ter caráter consultivo ou deliberativo e neste caso podem ter caráter legislativo ou executivo.

Paro (2006) observa que a escola pública encontra-se tão transpassada por práticas autoritárias que o discurso liberalizante mal consegue escamoteá-las:

Há pessoas trabalhando na escola, especialmente em postos de direção, que se dizem democratas apenas porque são "liberais" com os alunos, professores, funcionários ou pais, porque lhe "dão abertura" ou "permitem" que tomem parte desta ou daquela decisão. Entretanto esse discurso não consegue encobrir é que, "se a participação depende de alguém que dá abertura ou que permite sua manifestação, então a prática em que tem lugar essa participação não pode ser considerada democrática, pois democracia não se concede, se realiza: não pode existir "ditador democrático". (PARO, 2006, p. 18-19).

Segundo Paro (2001), um dos maiores problemas dos conselhos escolares está no caráter burocrático que imprime às decisões, que são deslocadas da esfera política para a esfera técnico-administrativa. Embora a existência de uma legislação possa induzir ações democratizantes, não se pode esperar uma imediata implementação de formas colaborativas de trabalho coletivo. A constituição de um habitus democrático é um longo processo, que implica não apenas em mudanças das estruturas oficiais da escola, mas em uma gradual mudança na cultura local, que deve introduzir a participação de todos os segmentos da comunidade escolar em todos os aspectos da gestão.

\section{As formas conciliatórias, clientelistas e de controle dos conselhos escolares}

O caráter clientelista das relações políticas do campo educacional é uma das características que impedem a democratização da escola. Como observou Marilia Sposito (1989), embora seja gerida e mantida pelo aparato estatal, a escola brasileira não é, em sua concepção política, necessariamente pública. Se aplicarmos aqui a distinção entre público e estatal, segundo a qual a concepção de público seria definido pelas orientações e finalidades estabelecidos pela população enquanto a orientação estatal obedeceria a finalidades e propósitos do Estado, pode-se concluir que os interesses do Estado não coincidem necessariamente com as proposições da população. Sposito (1989) afirma que, pelo contrário, o sistema de ensino, por caracterizar-se como estatal, permite a expansão do clientelismo, que enraizado na burocracia escolar, incentiva inversamente, uma mentalidade privatista da coisa pública. Os representantes do Estado comportam-se como donos do poder e senhores da escola, excluindo da direção dos destinos da escola a população cuja participação apenas é aceita de forma tutelada.

A estrutura administrativa da escola, determinada e articulada em grande parte a partir das orientações do diretor, que dela toma 'posse', a obtenção do consenso pelo servilismo ou pela troca de favores, a nomeação dos cargos de confiança nas instancias intermediarias ou superiores apoiada em relações tacanhas de clientelismo político, a falta de autonomia para a elaboração e execução de projetos pedagógicos no âmbito da unidade escolar, enfim, esse conjunto de fatores acaba por transformar a educação mantida pelo Estado num grande terreno onde prevalecem interesses pessoais, formas tradicionais de dominação política e concepções privadas de uma atividade que deveria ser essencialmente publica.(SPOSITO, 1989)

Um dos grandes instrumentos de legitimação das relações de poder na escola é a falsa necessidade de consenso que geralmente se exige nas decisões dos conselhos 
escolares. O conflito é considerado indesejável e as contradições próprias ao debate democrático são tidas como perigosas à vida coletiva. Essas concepções, em geral partilhadas pelos diversos agentes, leva a adoção de práticas conciliatórias que frequentemente acabam se constituindo em um processo de cooptação e clientelismo. Em última análise, as práticas de conciliação e clientelismo transformam as contradições próprias ao debate político em luta privada por privilégios.

As práticas conciliatórias e clientelista imprimem um caráter legitimador às relações de poder que circulam nos conselhos escolares. Dessa forma, mesmo um conselho deliberativo pode se constituir em instrumento de legitimação da autoridade da direção ou dos poderes governantes. A conciliação é uma das estratégias mais tradicionais de dominação e caracterizou, em diversos momentos de nossa história, as práticas dos conselhos de estado. Segundo Debrun (1983), a conciliação política, nos moldes brasileiros, é concebida como um acordo entre grupos ou indivíduos de poder político desigual. Seu desenvolvimento teve como propósito regular a relação entre atores desiguais, uns já dominantes e outros já dominados. E para permitir que os primeiros explorassem em seu proveito a transformação dos segundos em sócios caudatários. (DEBRUN, 1983, 15) Debrun observa que a conciliação é um investimento de reforço do poder desmobilizador, cooptando e reduzindo o poder de fogo de possíveis críticos dissidentes, de forma passiva.

Uma outra forma comum de cooptação política é o clientelismo. O clientelismo está vinculado à carga afetiva que se encontra envolvida nas relações de poder que caracterizam as instituições políticas brasileiras. Assim, em uma relação assimétrica, entre dominantes e dominados, é o conteúdo afetivo da relação que impede a ruptura. A amizade agiria como garantia mútua de proteção. Em instituições como as escolas surgem, com frequência um tipo de amizade que Bahia (2003) denomina instrumental, que une interesses privados comuns e propicia a criação das "panelinhas". As "panelinhas" são catalizadoras de elementos afetivos que podem ser usados para contrabalançar as demandas pessoais em relação às normas impessoais. Nas relações puramente clientelistas, as trocas são constituídas por privilégios econômicos ou proteção política que têm como pagamento, uma posição de respeito, subordinação e lealdade.

Conciliação e clientelismo constituem processos de mediação entre sujeitos com situação de poder assimétricos, que por meio da cooptação asseguram a legitimação do processo de dominação.

O processo de mediação atende à necessidade de desenvolvimento e criação de dispositivos de controle que devem ser internalizados, assegurando o controle por meio da sensação de que a contradição entre os objetivos dos indivíduos pode ser por um consenso coletivo. Este seria, para Benevides (2000), um dos aspectos que faria da gestão participativa, implementada no Brasil pós-reforma Gerencial, um mecanismo de cooptação dos movimentos sociais. Para ela, a ampliação da participação da sociedade civil, por meio dos Conselhos, pode constituir um dispositivos de controle social,

[...]. No plano da democracia política, no exercício efetivo de deveres e direitos políticos, nós estamos tendo esses problemas, de uma manipulação, de cooptação, de brecar mesmo essa participação autônoma, livre, democrática. Esse processo tem como contrapartida do lado da sociedade um desinteresse, um desencanto com a participação, que já foi muito mais intensa no final dos anos setenta pra cá, e mesmo, o que é pior do que tudo, um desencanto e um desinteresse pela própria ideia democrática. O mais perigoso aí é que o descrédito nas instituições políticas e democráticas ultrapassa a figura das pessoas, dos executivos, dos parlamentares, para atingir o próprio cerne da ação política, acaba se 
transformando num descrédito na ação política e na sua capacidade transformadora. Então, passa-se a ter uma atitude na vida social que é o oposto de qualquer ideia de cidadania democrática, que é o das estratégias individuais, do "salve-se quem puder", da "justiça pelas próprias mãos", excluindo qualquer possibilidade de um mínimo de solidariedade, no sentido do sólido social, e de qualquer tipo de participação mais ativa na sociedade. (BENEVIDES, 2000, p.01)

No caso do campo educacional, o processo de mediação se apresenta como uma aliança entre as restrições e coerções do sistema político e os privilégios oferecidos aos indivíduos. Os agentes escolares comportam-se como legitimadores da política governamental e os agentes da comunidade são vistos como possíveis elementos cooptáveis por meio de favorecimentos ou de uma falsa sensação de consenso.

As práticas conciliatórias encontram-se amplamente difundidas nas estruturas escolares e tem sido usadas como forma de anular a potencial ação política dos conselhos. Próprias das formas tradicionais de ação política, as práticas de cooptação, conciliação e clientelismo têm se constituído em importantes aliados de diretores e agentes escolares na preservação das antigas formas de poder e na manutenção da velha ordem escolar. Essas práticas possibilitaram o esvaziamento político dos conselhos escolares, transformando o seu potencial emancipatório e transformador em caricaturas de democracia, eliminando as contradições cujo papel é essencial para o avanço do debate democrático.

\section{Os conselhos como espaço democrático e de emancipação política}

A concepção de conselhos sempre esteve presente nas propostas autogestionarias, inclusive no campo da educação. Desde a década de 1960 pensadores da educação como Lobrot e Frenet propuseram estruturas de ampliação da participação de alunos e pais, como o conselho cooperativo, que deveria assumir a totalidade das tarefas escolares. Para estes autores a própria instituição escolar deveria mudar e suas propostas autogestionárias propunham um processo educativo mais igualitário.

Segundo Martins (2002) a concepção autogestionária tinha como meta tirar o excessivo controle da escola das mãos do Estado, permitindo que a educação propiciasse a construção de uma sociedade realmente democrática. Para tanto, as escolas deveriam construir um projeto pedagógico autônomo e articulado ao conjunto das lutas políticas. Esses projetos pretendiam romper com o tecnicismo, o racionalismo, a divisão técnica do trabalho, a fragmentação do conhecimento, em suma, a separação entre quem planeja e quem executa. (MARTINS, 2002). A autogestão das escolas constituiria, assim, um projeto de ruptura com a política educacional estatal, centralizadora, burocratizada e sem espaço para a participação democrática na administração, planejamento e avaliação da educação.

A partir da década de 1990 as Conferencias internacionais e os organismos multilaterais incorporaram em seu discurso gerencial a concepção de democratização da educação e a participação política. Programas de educação governamentais passaram a propor a democratização na gestão das escolas e a participação política passou a significar uma valorização cada vez maior da esfera local. Entretanto deve-se destacar que a concepção de participação adotada nem sempre significava uma mudança das relações de poder. Frequentemente participação significava a defesa de direitos individuais e econômicos, distanciando-se da proposta de constituição de um espaço de autogestão, isto é de uma gestão política coletiva de tudo que dissesse respeito a escola. Essa ressignificação da concepção de participação política acabou por substituir as ideias de ação coletiva e emancipatória, que estavam na origem da concepção dos conselhos. 
O conselho escolar, tal como é previsto na legislação atual, deveria se constituir como um espaço de deliberação sobre os destinos da escola. A instauração do conselho deveria implicar no estabelecimento de um campo onde se confrontariam posições antagônicas e conflitos com o propósito de se conhecer o que pensam os diferentes interlocutores. Nesta perspectiva, o conselho seria um espaço público, onde diferentes agentes poderiam assumir posições divergentes sem comprometer sua condição de igualdade.

O conselho escolar, de caráter democrático, contrapõe-se à tradição patrimonialista do Estado brasileiro, que exibe relações sociais permeadas pelo clientelismo e pela política do favor. Nessa perspectiva, o Conselho Escolar seria o território que possibilitaria a discussão, negociação e encaminhamento das demandas educacionais, (Aguiar, 2008) favorecendo, desse modo, a participação social e a promoção da gestão democrática. Nessa direção, configura-se o conselho escolar como uma instância de discussão, acompanhamento e deliberação, na qual se busca incentivar uma cultura democrática, substituindo a cultura patrimonialista pela cultura participativa e cidadã (AGUIAR, 2008 p. 138)

É importante anotar que o papel dos conselhos escolares no processo educativo não se restringe ao de instancia deliberativa. Em sua análise sobre a educação para a democracia, Benevides (1996) afirma que este processo comporta duas dimensões: uma voltada para a formação em valores republicanos e democráticos e outra voltada para a tomada de decisões políticas. A educação para a democracia teria, assim, uma dimensão pedagógica de formação e preparação para a ação política, por meio do qual a população compreenderia o significado do processo decisório e o da ação de governar. Segundo Benevides isso significa, concretamente, a preparação para o julgamento político necessário à tomada de decisões.

Paro salienta a dupla constituição democrática da gestão escolar:

[...] voltando para a questão da gestão escolar, é possível afirmar que, para dar conta de seu papel, ela precisa ser, pelo menos, duplamente democrática. Por um lado, por que ela se situa no campo das relações sociais onde, como vimos, se torna ilegítimo o tipo de relação que não seja de cooperação entre os envolvidos. Por outro, porque, também como vimos no início deste trabalho, a característica essencial da gestão é a mediação para a concretização de fins; sendo seu fim a educação e tendo esta um necessário componente democrático, é preciso que exista coerência entre o objetivo e a mediação que lhe possibilita a realização, posto que fins democráticos não podem ser alcançados de forma autoritária. (PARO, 2001, p. 52)

Tomada neste sentido, a gestão democrática apresenta-se essencial, tanto para o processo de democratização das relações escolares, como para a constituição de um processo de educação para democracia. A democracia constitui não apenas uma forma de governo mas também uma tomada de posição ética. Meios e fins pertencem ao mesmo processo e não podem ser separados. Por isso, a gestão democrática não pode prescindir de meios democráticos de gestão e o principal meio de democratização da ação educativa e das relações escolares é o conselho de escola, formado de forma representativa e com poder decisório. O Conselho escolar introduz uma concepção que pode ser identificada a um autogoverno, na medida em que se reconheça o seu caráter deliberativo e de instancia máxima de decisão.

Concebida como uma ética, a democracia constitui a própria forma do conselho e depende da participação de todos aqueles que, de uma forma ou de outra, estão 
relacionados à vida escolar. Isto significa que a gestão da escola deve partir da democracia como princípio estruturante de todas as suas práticas. Em muitos casos, entretanto, a democracia é tomada como uma técnica de gestão reduzida à consulta de alguns membros da comunidade não representativos de sua totalidade.

Bruno (2002), chama a atenção para o fato de que a participação e a gestão democrática não podem ser reduzidas a uma técnica de gestão do trabalho:

É na prática de auto-gestão dos envolvidos no processo de educação das novas gerações da classe trabalhadora, pais, alunos e professores, que, criando seus próprios espaços públicos onde os interesses são debatidos naquilo que têm de comum e na diversidade em que se apresentam, se poderá chegar à formulação de alternativas reais às hierarquias de comando de poder que nós é imposto, esteja este configurado na sua forma convencional ou em rede, como se gosta tanto de apresentá-lo. (Bruno , 2002: p.38)

A concepção segundo a qual os Conselhos Escolares são a instancia mais elevada na deliberação do processo de gestão da escola prevê a constituição dos conselhos por meio de eleição direta de seus pares. Trata-se de uma aspecto essencial para a constituição de um habitus democrático. Como observa Dourado (2004) a eleição, por si só, não é garantia da democratização da gestão: é necessário referendar essa modalidade de escolha como um importante instrumento, a ser associado a outros, para o exercício democrático. (DOURADO, 2004, p. 38)

O conselho não pode ser o último passo para a resoluções de problemas, mas cabe a ele a intervenção em todas as esferas da vida escolar imprimindo-lhes uma dinâmica democrática. O processo decisório é muito mais complexo do que faz supor uma abordagem linear e mecânica. Os diferentes agentes imprimem um caráter às suas ações que pode ser autoritário ou democrático, dependo de suas estratégias, de como gerem os seus conflitos e, sobretudo, dos processos de aprendizagem que marcam o processo de sua ação. Nesse quadro, as ações do conselho escolar têm como característica fundamental construir e transformar o espaço escolar atribuindo-lhe um sentido coletivo no interior dos quais os agentes vão se reconhecer e (re) definir suas posições.

Em geral, uma concepção mais mecânica dos conselhos estabelece sua ação como espaço de soluções de problemas e atribuidor de sanções. A ação do conselho é política, isto significa que deve construir uma nova representação de seu campo de atuação como instrumento de implementação de uma política democrática na escola.

Dado o caráter conflituoso próprio ao conselho, não se pode esperar a produção de consensos. Por isso é indispensável a compreensão do caráter intrinsecamente contraditório de toda política. Segundo MULLER e SUREL:

[...] toda política pública se caracteriza por contradições, até incoerências, que devem ser levadas em conta, mas sem impedir que se defina o sentido das condutas. [...] Simplesmente, este sentido não é de forma alguma unívoco, porque a realidade do mundo é ela mesma, contraditória, o que significa que os tomadores de decisão são condenados a perseguir objetivos em si mesmos contraditórios (MULLER; SUREL,2002,p.1718)

Não se pode reduzir analiticamente a gestão escolar à realização eficiente dos objetivos institucionais da escola . (Krawczyk, 1999) Essa concepção mecânica e finalista da gestão exclui seu aspecto ético e substantivo, porque fragmenta o complexo processo dessa gestão, perdendo de vista seu caráter eminentemente ético. Nesta perspectiva, Bordignon e Gracindo observam que: 
o poder não se situa em níveis hierárquicos, mas nas diferentes esferas de responsabilidade, garantindo relações interpessoais entre sujeitos iguais e ao mesmo tempo diferentes. Essa diferença dos sujeitos, no entanto, não significa que um seja mais que o outro, ou pior, ou melhor, mais ou menos importante, nem concebe espaços para a dominação e a subserviência, pois estas são atitudes que negam radicalmente a cidadania. As relações de poder não se realizam na particularidade, mas na intersubjetividade da comunicação entre atores sociais. Neste sentido, o poder decisório necessita ser desenvolvido com base em colegiados consultivos e deliberativos. (BORDIGNON e GRACINDO, 2002, p. 151152).

No processo dinâmico social,

os conselhos escolares adquirem vida e forma material nas articulações relacionais entre os atores sociais que os compõem; na forma como pais, alunos, professores, funcionários e Direção apropriam-se do espaço do conselho, enquanto o constroem, de maneira dinâmica e conflitiva, utilizando-se,neste processo, de seus saberes [...] Portanto, o conselho escolar é um processo e um produto de uma construção coletiva, cotidiana e particular de cada escola. (WERLE,2003, p. 102).

Segundo Werle (2003) não existe conselho vazio, ele é o que a comunidade escolar estabelece, constitui e operacionaliza. Isto significa que cada conselho tem a face das relações que nele se estabelecem. Se forem estabelecidas relações de responsabilidade e respeito, permitindo o compartilhamento de funções deliberativas que permitam discutir e definir prioridades, possivelmente teremos conselhos mais ativos. O conselho escolar, quando constituído como o resultado do movimento social, faz com que o próprio ato de participar e reivindicar se consolide como processo educativo.

\section{Considerações Finais}

Um dos principais problemas analisados neste estudo refere-se à expectativa que se tinha, nos primórdios da instalação dos conselhos, de que ele propiciaria uma mudança estrutural nas relações de poder no interior das escolas.

É interessante que se observe como os agentes escolares demonstraram uma resistência à mobilização da população usuária da escola pública. Diretores de escola, professores, e demais autoridades e governantes educacionais tem evidenciado um claro desinteresse e distanciamento das reivindicações expressas pela população usuária da escola pública.

Toda a potencialidade evidenciada pelas lutas sociais em prol da democratização da escola foram anuladas pela implementação de diretrizes de participação burocratizadas e impessoais. As autoridades, escolares ou governamentais, com base nos dispositivos legais, estabeleceram e definiram, de forma tutelada a participação da comunidade na escola. À comunidade é vetada a livre manifestação de seus interesses e a escolha da forma de sua organização. A estrutura dos conselhos não são pensadas a partir da necessidade de participação da comunidade, mas a partir dos problemas tal como são percebidos pela equipe gestora da escola. Tudo se passa como se existisse apenas um ponto de vista sobre a escola, o de seu gestor. Todos os demas são relegados à condição de não existencia ou irrelevancia.

Ao final, o que se pode observar foi o descrédito da população diante do distanciamento demonstrado pelas autoridades escolares, em relação aos propósitos que teriam originado as reivindicações sociais pela democratização da escola. Uma espécie de 
retração cética, conjugada com a manutenção das formas tradicionais de relações de poder, reforçou a ideia de que a escola é refratária a mudanças em sua estrutura de poder. Ao mesmo tempo, a adoção de formas gerenciais por parte dos diferentes governos não permitem que a comunidade escolar experimente a autonomia necessária para a constituição de um espaço realmente democrático. Além disso, a permanência da autoridade tradicional do diretor contribui para a persistência de práticas conciliatórias e conservadoras. Embora se adote um discurso democrático, os procedimentos habituais atestam a tenacidade da condição centralizada e autoritária da gestão da escola.

Acostumados às tradicionais relações de poder, os diretores permanecem como senhores da escola e assimilam a concepção de conselhos escolares às antigas praticas das Associações de pais e mestres, única forma institucional que reconhecem para a participação da comunidade. Este problema resulta, principalmente, do fato do diretor permanecer como o responsável pela constituição, implementação e presidência dos conselhos escolares. Do ponto de vista estrutural, o diretor não percebe nenhuma mudança e considera a implantação de conselhos escolares apenas uma mudança de nome em relação às APMs.

As lutas sociais que levaram a introdução da gestão democrática na educação evidenciam a latente potencialidade transformadora dos conselhos. As experiências acumuladas não podem ser desprezadas, mas recriadas e reinventadas por meio da instituição de novas formas de participação política, que incorporem a potencialidade transformadora dos movimentos sociais. Os conselhos escolares são instituições, e como tais exigem um permanente exercício criação, recriação, invenção e reinvenção de sua própria instituição. Entretanto, mantidas as condições atuais, teremos permanentemente uma farsa que, embora não consiga atrair ou iludir a população usuária da escola, parece atender aos interesses tanto dos governantes quanto dos gestores escolares.

\section{Referencias}

ABRANCHES, M. Colegiado escolar: espaço de participação da comunidade.São Paulo: Cortez, 2003.

AGUIAR, M.A. Gestão da educação básica e o fortalecimento dos Conselhos Escolares in Educar, Curitiba, n. 31, p. 129-144, 2008. Editora UFPR

ANDRADE, D. (org.). Política e Gestão da Educação. Belo Horizonte: Autêntica, 2002.

AREDES, A. P. J. As políticas públicas que originaram as instâncias pró-democráticas de participação no estado de São Paulo ,ORG \& DEMO, UNESP: Marilia /l.3, p.77-88, 2002 AUTHIER, D. A esquerda alemã (1918-1920). Porto, Afrontamento, 1975.

BAHIA, Luiz Henrique Nunes. O poder do clientelismo - raízes e fundamentos da troca política. R.J.: Renovar, 2003.

BARROSO, J. O estudo da escola. Porto: Ed. Porto. 1996.

BENEVIDES, M.V. M. Educação para a democracia, in Lua Nova no.38 São Paulo Dezembro, 1996, disponível em http://dx.doi.org/10.1590/S0102-64451996000200011 acesso $05 / 2013$

O que é formação para a cidadania? Entrevista a Silvio Caccia Bava em jan. 2000. Disponível emhttp://pt.scribd.com/doc/56291685/o-que-e-formacao-paracidadania Acesso em:12/04/2013. 
BORDIGNON, Genuíno e GRACINDO, Regina Vinhaes. Gestão da Educação: município e escola. In: FERREIRA, N. S. e AGUIAR, M. A. (Orgs.) Gestão da Educação: impasses, perspectivas e compromissos, São Paulo, Cortez, 2000.

BRASIL. Constituição da República Federativa do Brasil. Promulgada em 5/10/1998.

BRASIL. Lei de Diretrizes e Bases da Educação Nacional: Lei n. 9394/1996. Disponível em: 〈www.mec.gov.br/lrgis/default.sthm>. Acesso em: 30/3/2006.

BRASIL, MINISTÈRIO DA EDUCAÇÃO, SECRETARIA DE EDUCAÇÃO BÁSICA, Conselho escolares, Gestão democrática da educação e escolha de diretores, Programa Nacional de fortalecimento dos conselhos escolares, Brasília, MEC, SEB, Novembro de 2004.

BRUNO,L. Onde procurar o democrático? In: ANDRADE, D. (org) Política e Gestão da Educação Belo Horizonte: Autêntica, 2002.

CAMPOS, M. M.M. As lutas sociais e a educação. In Cadernos de Pesquisa, no. 79, p.5674, nov. 1991.

CURY, Carlos R. Jamil. Os conselhos de educação e a gestão dos sistemas. In:

FERREIRA, N. S.C.; AGUIAR, M. A. (orgs.). Gestão da educação:impasses, perspectivas e compromissos. São Paulo: Cortez, 2000.

CISESKI, A.A. Aceita um Conselho? Teoria e pratica da gestão participativa na escola pública. Dissertação de Mestrado, FEUSP, 1997

Aceita um Conselho?Como Organizar o Colegiado Escolar. S.P.:Cortez,

2002

DEBRUN, Michel. A conciliação e outras estratégias. S. P.:Brasliliense, 1983.

DOURADO, Luiz F. et al. Conselho Escolar, gestão democrática da educação e escolha do diretor. Brasília: MEC/SEB, 2004

GOHN, M. G. Movimentos Sociais e Educacăo . Săo Paulo, Cortez, 1992

Conselhos gestores e participação sociopolítica.São Paulo: Cortez , 2001.

GETZLER, I. Outubro de 1917, o debate marxista sobre a revolução na Rússia.

In Hobsbawm, Eric, História do Marxismo, Vol. 5 . pp25-74. R.J.: 1985, Paz e

Terra

GRAMSCI, A.; BORDIGA, A. Conselhos de fábrica. São Paulo: Brasiliense, 1981.

KRAWCZYK, N . A gestão escolar: Um campo minado... Análise das propostas de 11 municípios brasileiros in Educação e Sociedade, vol.20 n.67 Campinas Agosto. 1999

LUIZ, M.C. SILVA, A.L. ; GOMES, R.M. Indicadores de funcionamento do conselho escolar em alguns municípios paulistas. In LUIZ, M. C. (org.) Conselho Escolar, algumas concepções e propostas de ação. S.P.: Xamã , 2010a

Algumas reflexões sobre a prática da gestão democrática na cultura e organização escolar. In Revista Eletrônica de Educação, v. 4 n. 2, nov. 2010 b disponível in http://www.reveduc.ufscar.br/index.php/reveduc/article/viewFile/174/100 aceso abril $\underline{2013}$.

MAFESSOLI, M. O conhecimento comum. Porto Alegre:Sulina Ed.2007. 
MARTINS, A. M. Autonomia e Educação : A história de um conceito, in Cadernos de Pesquisa, n. 115, março/ 2002 p. 207-232, março/ 2002

MULLER, P.; SUREL, Y. A análise das políticas públicas. Pelotas: Educat, 2002.

OLIVEIRA,D.A;ROSAR,M.F.F.B.,.: Política e Gestão da Educação. B.H,:Autêntica, 2002.

PARO, V. H. Escritos sobre Educação. São Paulo: Xamã, 2001

Gestão democrática da escola pública. 3. ed. 11. imp. São Paulo: Ática, 2006.

RISCAL, S.A.;GANDINI, R.P.C. A gestão da educação como setor público não estatal e a transição para o estado fiscal no Brasil, in OLIVEIRA,D.A ; ROSAR,M.F.F.B.,.: Política e Gestão da Educação. B.H,:Autêntica, 2002.

RISCAL, S.A. A Gestão Escolar no cotidiano da escola. São Carlos : Ed.UFSCar, 2009

Considerações sobre o conselho escolar e seu papel mediador e conciliador. In

LUIZ, M. C. (org.) Conselho Escolar, algumas concepções e propostas de ação. S.P.:

Xamã , 2010

ROTOLO, Tatiana de M. S. O Socialismo Democrático segundo Rosa Luxemburg.

Dissertação de Mestrado. FFLCH-USP, 2007

SÃO PAULO, Governo do Estado. Decreto 10623/77 de 26 de outubro de 1977 Aprova o Regimento Comum das Escolas Estaduais de $1^{\circ}$ Grau e dá providências correlatas disponível em http://governo-sp.jusbrasil.com.br/legislacao/211193/decreto-10623-77\# Acesso em 23 de junho de 2013

SÃO PAULO, Governo do Estado - Lei Complementar $n^{\circ} 375$, de 19 de dezembro de 1984, Altera disposições da Lei Complementar $n^{\circ}$ 201, de 9 de novembro de 1978 .

Disponível em :http://governo-sp.jusbrasil.com.br/legislacao/195676/lei-complementar375-84. Acesso em 23 de junho de 2013

SÃO PAULO, Governo do Estado - Lei Complementar $N^{\circ} 444$, de 27 de Dezembro de 1985 - Dispõe sobre o Estatuto do Magistério Paulista e dá providências correlatas.

Publicada no DOE-I 31/12/1985, p. 1. Disponível em:

http://www.al.sp.gov.br/repositorio/legislacao/lei\%20complementar/1985/lei\%20complem entar\%20n.444,\%20de\%2027.12.1985.htm. Acesso 06 de junho de 2013.

SPOSITO, M.P. O povo vai ŕ escola: a luta popular pela expansão do ensino público. São Paulo, Loyola, 1984.

. A ilusão fecunda: a luta por educação nos movimentos populares. Tese de Doutorado. São Paulo, FE-USP, 1988.

Redefinido a Participação Popular na Escola. In: Cadernos do CEDI. São

Paulo, n. 19, pp.61-67, jan. 1989.

Educação, gestão democrática e participação popular. Educação e

Realidade. Porto Alegre, n. 15, v. 1, p. 52-56, Jan./Jun. 1990.

TRATENBERG, M. A revolução Russa. S.P.: Editora Unesp, 2004

UNESCO. La Autogestión en los sistemas educativos. Paris,: Unesco, 1981.

WERLE, F. O. C. Conselhos escolares: implicações na gestão da escola básica. Rio de Janeiro: DP\&A, 2003. 
Recebido em julho-12

Aprovado em fevereiro-13

\section{Notas}

1 Professor do Departamento de Educação- DEd e do Programa de Pós-Graduação em Educação da Universidade Federal de São Carlos (UFCar). Email: celsocon@ufscar.br

2 Professora do Departamento de Educação- DEd e do Programa de Pós-Graduação em Educação da Universidade Federal de São Carlos (UFCar). Email: mceluiz@ gmail.com

3 Professora do Departamento de Educação- DEd e do Programa de Pós-Graduação em Educação da Universidade Federal de São Carlos (UFCar). Email: riscal@ uol.com.br

${ }^{4}$ As OCIPs - Organização da Sociedade Civil de Interesse Público - São organizações da sociedade civil , de caráter não governamental sem fins lucrativo que por meio de parcerias interagem com governos federal,estdual e municiapal para elaboração e implementaçao de políticas sociais.

5 Rosa Luxemburso pertencia ao partido espartaquista (Spartakus) constituído também por Liebnecht, Mehring e Meyer, entre outros. Contemporânea da revolução russa, Rosa Luxemburgo era crítica do centralismo soviético. Para Rosa Luxemburgo, o socialismo tinha entre os seus pré-requisitos a liberdade política. A revolução bochevique teria, segundo ela, suprimido o direito de livre associação, de reunião e de liberdade de imprensa e portanto impedia a constituição de um legítimo socialismo. Luxemburgo afirmava que só a experiência é capaz de corrigir e abrir novos caminhos; só uma vida que fervilhe sem obstáculos imagina mil formas novas, imprevistas, dá origem a uma força criadora. 